\title{
The Modernity of Measure for Measure
}

\section{The Politics of Spinning Shakespeare}

\section{VERONIKA SCHANDL}

Abstract: This paper looks at two twentieth-century rewritings of Shakespeare's Measure for Measure: one by Bertolt Brecht, who in 1933 wrote a parable-play on contemporary German social politics entitled Die Rundköpfe und die Spitzköpfe (The Roundheads and the Peakheads), and one by Charles Marowitz, who in 1975 finished his Variations on Measure for Measure, a play re-written after, and partly as a reaction to, his unjust arrest for shoplifting and vagrancy. As the contexts of their birth also indicate, both plays called upon Measure for Measure to reflect on the nature of justice and its relation to politics, but, aside from their political stance, the two dramas differ largely in the way they work with Shakespeare's text. Indeed, one could argue that if we take the "fidelity to Shakespeare's text" as the gauge of our imaginary spectrum of adaptations, they, at first glance, seem to occupy almost the opposite ends: while Brecht distances himself from the original almost completely, Marowitz relies on the play's text closely, only to concoct from its pieces a surprisingly different ending. However, this essay wishes to argue that, in spite of their different textual approaches, the two Measure for Measure spinoffs are alike in several aspects.

One does not have to argue long for the problematic nature of Measure for Measure, since the play is one of those three - or, in some understandings, four - plays in the Shakespearean oeuvre which, with their loose endings and unsettling structural difficulties, spurred the invention of a new generic term - that of the problem play, or problem comedy. Probably written for the Globe audience, but definitely performed at court in 1604, the play has been handed down to us in only one version, the already amended text published in the 1623 Folio. Its lack of publication in quarto format might suggest a lack of success on the stage, corroborated by the dearth of productions in the seventeenth and eighteenth centuries. Yet 
the Folio text, altered by Middleton, already reveals that it is precisely its problematic nature that makes the play intriguing and challenging material for later rewriters.

The list of adaptations goes back to the Restoration, when two versions, William Davenant's The Law Against Lovers (1662) and Charles Gildon's Measure for Measure; or, Beauty the Best Advocate (1700), turned to Shakespeare's play. The nineteenth century saw Richard Wagner's opera, Das Liebesverbot, and Alexander Pushkin's poetic tale, Angelo, both based on Shakespeare's Measure for Measure. Still, neither in these adaptations nor in the still heavily cut "restored" Shakespearean text that was staged well into the second part of the twentieth century, did the play have much success in the theatre. It did not fail to stir up scholarly discussions though - questions concerning its genre, its authorship, or its political and social aspects have intrigued readers from Coleridge to Wilson Knight. However, it took the much altered theatrical and social climate of the post-Second-World-War era for the play at last to become successful in performance as well. Directors, intrigued by the silences the play leaves to be filled, starting with Peter Brook in 1950, who reinterpreted the social context of the comedy, and followed by John Barton, who, challenging Brook, took the play in a much darker direction, all over the world have successfully managed to rethink the comedy for new audiences. Often presented as a social commentary on contemporary issues, Measure for Measure in the twenty-first century is one of the more popular Shakespeare pieces in production. ${ }^{1}$

The reading of Shakespeare's play as a piece reflecting on contemporary conditions is also what links Bertolt Brecht and Charles Marowitz and their versions of Measure for Measure. Brecht and Marowitz are two playwrights, two directors with strong visions of the theatrical, as well as two politically engaged theatre makers with a love-hate relationship with William Shakespeare and the kind of theatre his plays traditionally came to be associated with. Both turned to Shakespeare's Measure for Measure to challenge these traditions: Brecht in 1933, when he wrote a parableplay on contemporary German social politics entitled Die Rundköpfe und die Spitzköpfe (The Roundheads and the Peakheads), first presented in 1936, and Marowitz in 1975 with his Variations on Measure for Measure, a play re-written after, and partly as a reaction to, his unjust arrest for shoplifting and vagrancy. As the contexts of their birth also indicate, both plays called upon Measure for Measure to reflect upon the nature of justice and its relation to politics, but, aside from their political stance, the two dramas differ largely in the way they work with Shakespeare's text. Indeed, one could argue

1 For the productions of the play, see Hampton-Reeves. 
that if we take the "fidelity to Shakespeare's text" as the gauge of our imaginary spectrum of adaptations, they, at first glance, seem to occupy almost the opposite ends: while Brecht distances himself from the original almost completely, Marowitz relies on the play's text closely, only to concoct from its pieces a surprisingly different ending. However, this essay wishes to argue that, in spite of their different textual approaches, the two Measure for Measure spinoffs are alike in several aspects.

In 1931, Brecht began to work on the first version of Roundheads and Peakheads, ${ }^{2}$ fulfilling a request from the director of the Berliner Volksbühne, Ludwig Berger, who wished to present modernised adaptations of Shakespeare's plays. Berger was famous for his un-Reinhardtian take on Shakespeare, rejecting a realistic presentation of Shakespeare's plays, as well as being “a strict reformer who would no longer permit Shakespeare to be adapted to the stage but demanded that the stage be adapted to Shakespeare" (qtd. in Hortmann 75). Maybe this is the reason why the adaptation was never finished. The collaboration with the Volksbühne resulted instead in something far more intriguing: a genuine play that exhibits all the characteristics of Brechtian epic theatre and relies on Shakespeare's Measure for Measure for inspiration. Although it was neither one of Brecht's most popular plays (it was staged just once in the playwright's lifetime, in 1936, in Copenhagen) nor a frequent presence on the world stage, ${ }^{3}$ Roundheads and Peakheads deserves special attention for the way it appropriates Shakespeare's Measure.

Brecht, who famously said that "Wir können Shakespeare ändern, wenn wir ihn ändern können” (Brecht, Werke 23:395), ${ }^{4}$ engaged in rewriting Shakespeare all his life. His interest in Measure for Measure was spurred by the play's engagement with power and morality:

Measure for Measure is seen by many as the most philosophical of Shakespeare's works, but it is without doubt his most progressive play. It demands the aristocracy to be measured by other measures than they themselves would like to be measured by.

2 I use the edition based on the Copenhagen stage version: Brecht, Die Rundköpfe und die Spitzköpfe. The English translation in Brecht's Collected Plays relies on the later version of the play that Brecht revised for inclusion in his collected works.

3 For a post-WWII stage history of the play, see the information in Brecht, Die Rundköpfe.

4 "We can change Shakespeare, if we can change him" - that is, if we are able to actually change him. 
And it shows that they cannot expect their subjects to follow a moral code they themselves do not adopt. (Bahr 200, my translation)

In his rewriting he wished, therefore, to follow the same "fortschrittlichen Standpunkt" ("progressive standpoint") that Shakespeare, whom Brecht characterises as the great writer of humanism (Bahr 200), also stood for.

Brecht's idea of a "historisierende Theater" (Werke 22.1:209) demanded that the general questions raised in Measure for Measure about the conflicting concepts of justice, love, and sacrifice be repositioned in a historically recognisable, contemporary context, which in turn would encourage the spectators to view the events of the play more critically and recognise the relevance of the stage events to their own lives. Therefore, Brecht used the Shakespearean play as raw material for a parable on social injustice and the hazards of racism. The ruler of his stage kingdom leaves in order to avoid introducing harsher financial measures in his land - among others a new tax on salt - which would be necessary to circumvent the country's financial bankruptcy. ${ }^{5}$ Fearing that the peasants already revolting in the south would start a revolution which would overthrow his government, he follows the ingenious guidance of his advisor, Escaler, to appoint to power his opponent, Iberin, who runs on a right-wing agenda of racial segregation. He does so in the hope that Iberin's divisive politics would break up the union of the peasants and enable him to rule undisturbed. With this plot change, Brecht catapults the events of Measure for Measure into the early 1930s of his Germany, focusing on two vital contemporary issues: the financial and political deprivation of the working and peasant classes as well as on the growing influence of Nazi propaganda.

One could argue that no Shakespeare play would have provided Brecht with better opportunities to model contemporary German relations than the first scene of Measure for Measure, since the Duke's (in Brecht's play the Deputy Regent's) resignation and Angelo's (Iberin's) swift rise to power uncannily resembles Hindenburg's handover of the Chancellor's seat to Hitler. ${ }^{6}$ In the several versions of the play, one can see how Brecht tried to approximate his play as a more pointed allegory based on these current events (Bahr 235). Still, one cannot fail to notice Brecht's endeavour to appropriate the Shakespearean storyline as well. The combination of the two main structural

5 The land is no longer Vienna, but Yahoo, echoing both Swift's Gulliver's Travels in its name and a South-American country in its social structure.

6 The similarity is even more uncanny if we take it into account that Brecht finished the first version of the play (by January 1933) before the actual "Machtübergabe" on 30 January 1933. 
driving forces results in a play which is not, according to Julie Sanders' definition, truly an adaptation - that is, a commentary on a source, a "simpler attempt to make texts 'relevant' or easily comprehensible to new audiences and readerships" (19), since Brecht only very loosely follows Shakespeare's plot, and by filling the gaps of his source text, he references his contemporary reality instead of some previous historical literary antecedent. Neither is it, however, an appropriation- "a more decisive journey away from the informing source into a wholly new cultural product or domain" (26) - since the organisational principle of the plot is still Measure for Measure; indeed, the effort to be relevant but also to resemble the source results in a rather complicated plotline.

Brecht's way of spinning Shakespeare's play is probably closest to a jazz musician's way of following a given tune but also improvising around it, at the same time, providing the closest and the furthest means of adaptations. For instance, we do have the scene where the Duke decides he should leave for a while to hand over the uneasy job of fixing the economy to someone else, but here the Duke is surrounded by advisers who taint his original ideas and persuade him to put a politician in charge who is knowingly a politically divisive character. The echoes of Shakespeare's first scenes are still heard in the background, but a new layer of racial politics is added to its theme, enriching and diverting it at the same time.

The result of this technique is something unique: a play which contains all the characteristic features of Brechtian epic theatre - alienation effects presenting themselves in songs, posters, signs, and a distancing of actor and character; a historicising of the subject matter as well as an introduction of narrative elements and the display of the theatrical stage apparatus - but is at the same time a retelling of a Shakespeare play, fitting into the line of the most successful later reinterpretations of Measure for Measure by bringing the play closer to current political events. That Brecht succeeded in modernising the topic of the play is well demonstrated in the difficulties the drama faced in publication: although already in galley proof in 1933, it was banned and its copies were destroyed, so it only appeared in 1959. This delay in publication also gave Brecht the opportunity to refocus the play. He added a Prologue, which set the tone of the later versions, and emphasised the double focal points of "Rassentheorie" and the deprivation of the poor.

In the Prologue, the actors put on costumes which would later determine their social status, as well as a head mask, which in turn would establish their race, the other factor determining their fates. According to the racist theory presented 
in the play, Iberin, the new ruler of Yahoo, insists that the people of the country born with a peakhead (the Czuchs) are a race inferior to those born with a roundhead (the Czichs). They, therefore, are prosecuted and deprived of their human rights. The Prologue demonstrates how both one's body and social status can be fatally determining factors in one's life under an oppressive regime, but also how these arbitrary, yet richly connoted traits can be used and abused by oppressive demagogy.

Brecht also clearly sees how a theory of race can be used by those in power to establish scapegoats for their political mistakes. The same way the Jews were blamed for the decline of European civilisation by Nazi propaganda, the Czuchs are blamed for the financial miseries of Yahoo. They are described as lazy and morally corrupt, bereft of the Czuchish virtues of hard work and honesty. This demagoguery successfully divides the peasants in the play, making them forget their financial plights, while it is also successful in blackmailing the peakheaded aristocrats into financing the regime's war against the rebellious forces.

Aside from highlighting the potential threats of a racially prejudiced regime, Brecht aims at denunciating the corruption of the ruling classes and the church as well as the hopelessness of the peasants. Developing the social critical potentials already there in Measure for Measure, in two trial scenes the play delineates how those in power twist the law to enforce their own agendas, while using propaganda and doctrinal brainwashing to camouflage real social problems. One of the protagonists of the play, Callas, the peasant, a mixture of Shakespeare's Barnadine and German Volkshero, Michael Kolhaas, goes to town to force his landlord to cancel the taxes he is no longer able to pay. In a show trial, Iberin fools him by appealing to his previously non-existent Czichish race consciousness, which makes him forget his class and the very reason he started the process in the first place. With a false feeling of pride, he eventually ruins his chances for social betterment, and, in the second trial of the play, is pushed into financial deprivation with no hope of getting out of it. His fate exemplifies one of the morals the play intends to teach - that class solidarity only works among the rich, who protect their privileged status through fire and water. This axiom is appropriated for the members of the clergy in the play, too, who are solely interested in financial and not spiritual gains. They negotiate Isabella's prize to enter the convent as if bargaining for a horse, and later, indeed, they start a law case to get the two horses Callas takes from his landlord, to secure his family's survival. Instead of being a moral institution, for them the church is a covert means of enriching themselves, a means of accumulating wealth in the name of the Lord. 
In order to be able to criticise these social anomalies, Brecht changed the focus of Shakespeare's play. While Measure for Measure is interested in Isabella's and the Duke's story, Brecht brings the lesser characters to the forefront of his work. The main character of the play is, thus, Nanna Callas, the daughter of a peasant, who was sold at an early age as a concubine to her landlord, and is now living in a brothel in town. As a character, she is an amalgam of Shakespeare's Julia (being the former mistress of the play's Claudio figure, de Guzman) and Marianna (since she is forced to sleep with Iberin's right-hand man, in Isabella's place), her character is magnified to that of a raisonneur. Her fate exemplifies the destinies of the socially deprived that have no possibilities to escape deprivation. She is abused not only by her landlord, de Guzman, but even by her Madame, Mrs Cornamontis, who sells her off for good money to sleep with Iberin's deputy in Isabella's place, claiming that, since she is already blemished, one more atrocity would not much alter her situation. Nanna's disposition about the twists of fate she has to go through is summed up in the phrase she keeps repeating: "Ich bin skeptisch" (46).

Her stance is Brecht's stance, since the disbelief in the possibility of social progress is the final message of the whole play. Nanna sums up how, while the landlords feast upon their ultimate victory over the peasant army, they wish that the disturbances the poor have caused them in the past would be just temporary nuisances, which would now pass:

\author{
Und so sitzen sie denn und essen \\ Und wünschen uns zu vergessen. \\ Wir stehen mit leerem Magen \\ Und hören sie sagen: \\ Vielleicht vergeht uns so der Rest der Jahre? \\ Vielleicht vergehen die Schatten, die uns störten? \\ Und die Gerüchte, die wir kürzlich hörten \\ Die finster waren, waren nicht das Wahre. \\ Vielleicht das sie uns noch einmal vergessen. ${ }^{7}(108)$
}

While Nanna becomes the heroine of the play, Isabella is her antithesis. In Brecht's depiction she embodies the individualistic self-centredness of the rich and privileged.

7 "And so they sit down and eat / And wish to forget us. / We are standing here with an empty stomach / And hear as they say: / Maybe the rest of the year will be like this? / Maybe the shadows that disturb us will disappear? / And the rumours that we heard the other day / That were so sinister, are not true. / Maybe they will forget us once again" (my translation). 
While Brecht keeps certain aspects of her character (for instance, her insistence on the strictness of the convent), he distorts others to caricature. Isabella in the play thus becomes the satiric representation of bigotry and false spirituality. As Nanna explains, for her to become a nun is a choice of necessity - since she is a peakhead, she cannot get married to avoid the harshness of the law, she can only buy her freedom by becoming a nun and choosing a life of leisure out of the limelight (92). She is so focused on achieving this goal that she literally forgets to save her brother. It is not by chance that instead of a Lucio figure, in Brecht's play she is accompanied by ruthless and relentless lawyers.

While the focus is shifted, Brecht's play ends in a way that can almost be read as Shakespearean, since by the end of the play many of the vicissitudes the characters had to go through turn out to be pointless experiments, the aim of which was to cement the rule of the privileged and the defenselessness of the poor.

The Marxist teaching about the loss of class-consciousness resulting in the downfall of the working classes is a somewhat predictable message, at least according to Charles Marowitz, who criticises Brecht for choosing plays "which are already predisposed to his own ideology" (Marowitz Shakespeare 8). While Marowitz rejects Brecht's Marxist position, the two plays have more in common than first meets the eye. ${ }^{8}$ Both turn to Shakespeare with a clear political agenda in mind, and to communicate this, they both cut all the comic plot elements from Measure for Measure that enable to have a happy ending. When it comes to characters they both expand the role of the church, employ raisonneur characters to be mouthpieces of authorial commentary and emphasise the oppression of the underprivileged, especially the women. Although they do handle the Shakespearean text differently, these similarities do link their interpretations.

As Guido Almansi establishes, the way in which Charles Marowitz adapts Shakespeare resembles the Renaissance practice of a centone, "a literary genre which exploited lines of poetry from the classics in order to tell different stories from the ones of the ancient poets" (95). If we used a musical metaphor, where Brecht is a jazz artist, improvising around the Shakespearean theme, Marowitz's works would be remixes of Shakespeare. Indeed, Marowitz's own definition of what he does comes very close to the job of a centonista, or the remixer, since he claims that rewriting is not only an opportunity, but a task a contemporary playwright should not fail to take on.

8 In the essay I use the 2009 edition of the play, reprinted in The Marowitz Shakespeare. 
In an unusual metaphor, he likens the relationship of source text and its adaptation to a hamburger:

\begin{abstract}
When a playwright like Shakespeare provides us with the meat, it is almost a contemporary prerogative for us to add the potatoes, the onions and the relish. Our job is to retrace, rediscover, reconsider and reample the classics - not simply regurgitate them. I rethink therefore I am-said Descartes, or at least he should have. ("How to Rape Shakespeare" 15)
\end{abstract}

Mixing up Shakespeare's text, Marowitz made collages (of Hamlet and Macbeth), as well as what he called Variations (of The Merchant of Venice and Measure for Measure), or we could say remixes which closely follow the Shakespearean original up to a point but result in altered endings. Marowitz's idea that theatre works best on the basis of suspense and revelation ("How to Rape Shakespeare" 17) pays well in the case of Shakespeare, whose plays attract audiences with certain expectations about what they were about to see. Marowitz's Variations aim to shock them while disrupting these expectations by expounding one of the possible subtexts of the originals, which in Marowitz's words through reconditioning the text "become a dramatically acceptable reverse-truth" (Roar 97). Like a modern director, as he rewrites the plays and makes them more concrete ("How to Rape Shakespeare" 21-22), Marowitz presents his readings of the source texts, readings which almost always are reflective of contemporary political topics. The idea of reinterpreting Shakespeare with a contemporary political consciousness links him very much to Brecht, even if Marowitz is somewhat uneager to see these connections, and even if the end results could not be more different.

In both cases, we can see writers with strong visions of the theatrical at work. The difference in the plays is a result mostly of the different theatre they imagine. While Brecht's rewriting carries a certain measure of predictability in itself, since from the Prologue onwards it aims at demonstrating Marxist and anti-Nazi doctrines, the success of Marowitz's version relies heavily on the unpredictability of its outcome. Although Marowitz rejects Brecht's method, describing it as "reduction" and "oversimplification" (Marowitz Shakespeare 9), he also admits that "[i]n a theatre, one cannot put on the stage a kind of multifaceted resonating chamber called a 'classic' and allow all members of the public to draw their own conclusions from it. The artist proceeds from conclusions he has already drawn - from his reading of the text" "How to Rape Shakespeare" 22). In the case of Measure for Measure, one of Marowitz's 
preconceived notions comes very close to Brecht's assumption that "it is perhaps the most modern play in the classical repertoire" (Roar 103).

This modernity, according to Marowitz, is shown in how the play reflects on the unjust nature of law, not only in an abstract sense but also to our contemporary understanding of it, since we live in a society "where Watergate-styled corruptions are often the rule and not the exception" (Marowitz Shakespeare 21). Recognising the moral ambiguities in Shakespeare's play - as opposed to the old-fashioned morality of its source, Whetstone's Promos and Cassandra-Marowitz wishes to come down on one side, condemning the hypocrisy of those in power, and the phony ceremoniousness of the representatives of the law in the play: "I wanted the audience to be angry with the Duke, Escalus and Angelo in a way that Shakespeare's narrative would never permit," he confessed (Marowitz Shakespeare 21). To be able to do that, he must take the play in a darker direction - that is, to deprive it of a happy ending.

Strangely, the way he achieves it also implies a surprising amount of fidelity to Shakespeare's Measure. Except for a short insert from The Two Noble Kinsmen (214), all lines in the play come from Measure for Measure. Although rearranged from the first scene onwards, for the first half of the play, they closely follow the actions of the source text. So much so that even the puzzling gaps of Measure for Measure are not filled by Marowitz - i.e. we are given no reasons for the Duke's leave, except for maybe a few hints that he has a drinking problem. What we have instead is the introduction of the Bishop's character, using lines delivered by others in the original, whose appearance emphasises the increased role of the clergy in Marowitz's version, as well as a more intricately drawn power structure surrounding the Duke's abrupt leave. With the exception of Lucio, Marowitz cuts all the bawdy characters of the Viennese underworld from his play, an omission which deprives the Duke's departure of its moral ground and creates an almost suffocatingly closed onstage world, consisting mostly of the moneyed elite of Vienna.

Lucio is the sole character who is a remnant of the Viennese underworld. Since he only represents the other side of the coin, his role is magnified to a raisonneur figure, the "only character that would break through the fictional framework and address the audience directly" (Roar 87). Much of his text is a verbatim quotation from his lines in Shakespeare, yet he addresses not the disguised Duke, who is cut from the play, but the audience, resulting in a more open criticism of the workings of Viennese law. His lines communicate what Marowitz found crucially relevant in Shakespeare's play: that "the Law does not mete out justice. . . . 
Behind its austere facade, compromises, deals and plea-bargains mock the evils perpetrated on innocent victims" (Roar 102). This description pointedly sums up Marowitz's Variations, since like Brecht's play, this adaptation deals with revealing how class-solidarity only works among the rich and, as a consequence of this, how the poor are powerless to vindicate their rights.

Marowitz returns to the plot of Shakespeare's source, Whetstone's Promos and Cassandra, deletes the bed-trick and has Isabella ravished by Angelo. Playing with audience expectations, however, he seemingly leaves some getaway possibilities open for her, for instance, a dream sequence, in which we might hope for Isabella's close escape, just to get all doors slammed in our faces in the last scene, in which we witness Isabella becoming the helpless victim of male violence. The play exists in two versions, one of which ends on a similar banquet of the rich as we have seen in Brecht's play, during which the men jokingly enumerate the several women they took advantage of. The second version, published in Marowitz's Roar of the Canon, emphasises this kind of gender-based oppression even more. In this, Isabella is cornered by the four leading men of the play (the Duke, Angelo, Claudio, and Lucio) just to be served to the Duke as his new concubine. Her fate here echoes that of Brecht's Nanna's, with the conclusion that if women become the playthings of men, they lose their ability to fight against them.

Both Brecht and Marowitz dramatise violence against women. This is a topic that is absent, or just a never-fulfilled looming possibility in Shakespeare's play. It seems that, despite their different artistic stance, as well as the decades between them, both adaptors saw women as the most vulnerable and underprivileged segment of society. In both plays, it is women who lack class solidarity and a legal voice, the difference being that in Brecht's understanding, money can buy authority for women, as in the case of Isabella, but that comes at a price. She has to abandon her family as well as her chances of having a family and has to place herself under the custody of men (her lawyer and the priests). Marowitz sees no escape for women. His is a world where male gender solidarity overrides even class divisions, since at the end of his play, Lucio also joins the pact of men in rejoicing over the exploitation of women. To focus on socioeconomic and gender inequality, both plays modify the emphases of the Shakespeare play. They equally stress the oppressive power of the church and of the wealthy, who by the end of the plays unstoppably crush powerless individuals. While in Brecht's case this message is complicated by a racial doctrine, Marowitz's main interest lies in socio-economical inequalities. 
Measure for Measure has been one of the great Shakespeare discoveries of the twentieth century. The relevance of its inherent political topics made it a favourite among leading directors and audiences alike. Brecht's virtuoso jazz like improvisations on the Shakespearean themes on the one hand and Marowitz's playful remixing of Shakespeare's text on the other both prove that the play is a rich source of influence for politicised rereading.

\section{Works Gited}

Almansi, Guido. "The Thumb-Screwers and the Tongue-Twisters. On Shakespearean Avatars." Poetics Today 3.3 (1982), 87-100.

Brecht, Bertolt. Collected Plays. Vol. 4. Ed. Kuhn, Tom, and John Willett. London: Methuen, 2001.

—. Die Rundköpfe und die Spitzköpfe: Bühnenfassung, Einzelszenen, Varianten. Ed. Bahr, Gisela. Frankfurt am Main: Suhrkamp, 1979.

- Werke. Grosse kommentierte Berliner und Frankfurter Ausgabe. Eds. Hecht, Werner, and Jan Knopf et al. 30 vols. Berlin und Weimar: Aufbau, Frankfurt am Main: Suhrkamp, 1988-2000.

Hampton-Reeves, Stuart. Measure for Measure - A Guide to the Text and its Theatrical Life. New York: Palgrave Macmillan, 2007.

Hortmann, Wilhelm. Shakespeare on the German stage: The Twentieth Century. Cambridge and New York: Cambridge University Press, 1998.

Marowitz, Charles. "How to Rape Shakespeare and Emerge Psychologically Intact." Jahrbuch Deutsche Shakespeare Gesellschaft West 128 (1988): 7-25.

—. The Marowitz Shakespeare. London and New York: Marion Boyars Press, 2009.

- Roar of the Canon. New York: Applause, 2001.

Sanders, Julie. Adaptation and Appropriation. London and New York: Routledge, 2006.

\section{Contributor Details}

Veronika Schandl is associate professor at the English Department of Pázmány Péter Catholic University, Hungary. Her main research interests are Shakespeare in performance and twenty-first-century European theatre. Her book, Shakespeare's Plays on the Stages of Late Kádárist Hungary-Shakespeare Behind the Iron Curtain was published 
in 2009. Currently, she is working on two projects: one on Tamás Major, a controversial Socialist Hungarian director of Shakespeare, and another on contemporary Shakespeare burlesque productions. 